\title{
Towards the patenting of animals
}

The decision in the United States that engineered strains of animals are covered by patent law has begun a debate among European patents-watchers that must lead to an amendment of European law.

THE staff of Nature will be among the first people in the world to be able to grow a new variety of rose named 'Harold Macmillan' after the former British prime minister whose family publishing company founded and still owns this magazine. (The US Macmillan Publishing Company in the United States, just acquired by $\mathrm{Mr}$ Robert Maxwell's companies, was established by the Macmillan family, which sold it, together with the right to trade in the United States under the family name, in response to the British government's requirement that British companies should sell US assets to pay for wartime Lend-Lease of military equipment.) While the breeder of the Harold Macmillan rose will retain exclusive rights to sell the variety, there will be nothing to prevent green-fingered Nature staff from propagating the rose or using it as a stock from which to derive a new variety. By contrast, those who buy the 'oncomouse' on which a Harvard University group has been awarded a patent, and which is the first patented animal to be offered for sale (see page 300 ), will be much more tightly restricted in the uses they can make of it.

Why should there be such a disparity? In the United States as elsewhere, there is a tradition that plant varieties can be registered (giving breeders the sole right to sell them) but not patented, but there are no precedents on animals. But the latest developments on this front in the United States have triggered great anxiety and debate in Europe.

One catalyst of the debate is biotechnology, by means of which mere molecular biologists can produce plants and animals with new genes in a fraction of the time taken to produce a new variety traditionally. The 'oncomouse' is an example, the result of experimentally introducing a cancer-promoting oncogene into mouse eggs so that the gene is carried by the resulting 'transgenic' mice and can be transferred to subsequent generations. It has taken only four years to produce, patent and, now, sell the first 'oncomouse'. But the European Patent Office has so far not made up its mind about 'oncomouse'; if, as expected, it rejects the claim, that may simply mean that it wishes to force arbitration by an appeal board.

' 1992 ' is another catalyst of debate. That is the year in which trade barriers between the member states of the European Community will be eliminated. In anticipation, and to make it easier for companies to operate within a single commercial environment, there is a rush to standardize all manner of laws and regulations, among them the patent law for biotechnology.

Patent law in Britain, as in most European countries, specifically excludes the patenting of plant or animal varieties, while allowing patenting of microorganisms, which have come to include such modern entities as hybrid cell lines from which monoclonal antibodies are produced. One reason for the bias against higher organisms in the British Patents Act (1977) is that there is established and seemingly satisfactory legislation which provides plant breeders with rights over new varieties they produce. But the rights are limited, which is why those who grow the Harold Macmillan rose will be able not only freely to propagate and derive new varieties, but also to sell roses from the plant without paying a royalty.

But can this permissive system last? Difficulties had arisen even before the advent of gene technology, but have now been sharpened, especially in relation to the plant equivalents of transgenic animals. Can it be appropriate to apply the existing plant breeders' legislation which, like its equivalents throughout the world, was drawn up when plants that are now a reality, such as tobacco endowed with a gene that makes it resistant to a particular herbicide, were at best pipe-dreams?

The answer has to be no, not only because the means and genes involved can themselves be patented, but because a plant with a single new gene can be brought to the market and further engineered genetically, and more rapidly than by traditional breeding. And while it must be next to impossible faithfully to repeat the process by which a new variety is produced by traditional breeding, the addition of a defined gene can more easily be copied. Patent protection must therefore become the norm for transgenic plants, and fiscal systems will have to be devised whereby those who produce the new varieties can share the benefits their users will enjoy. So much is recognized in the draft proposal for a new European patent law for biotechnology issued by the European Commission last month.

That proposal also recognizes the need to provide patent protection for animals. Matters are simplified because there is no present system of protection of varieties to be taken into account. Whether, as some argue, there needs to be an equivalent of plant breeders' rights as well as patent protection will largely depend on the ingenuity of those who draft the new laws.

Where does this leave the practitioner molecular biologists, many of whom have retained their innocence? The jungle of existing and evolving patent law is often impenetrable, but some will have to be made to grasp the basics. But is there any more reason for the details of patent law to be familiar to practitioners than for the details of Southern blotting to patent lawyers? Biotechnology companies are probably able to provide the legal help their people need, but are research institutes and universities ready to meet what could be a taxing challenge?

\section{University nannies}

\section{The British government must decide whether its autonomous universities should be autonomous.}

Just what the British government intends for British universities is increasingly a matter for conjecture. Less than six months have gone by since the British Parliament was locked in battle over Mr Kenneth Baker's Education Reform Bill, now safely on the statute book. Among the several famous battles waged on that occasion were that in which the government agreed to accept that academic freedom is a concept that properly belongs in universities and that is not so vague that it cannot be enshrined in the English language. Among other things, the government also undertook that, in its new regime for the British universities, there would be an understanding that universities successfully following its exhortations to raise more money from private sources would no longer be penalized in the annual share-out of government subventions. Thus British law now includes the provision that the Universities Funding Council (the first word lacks an apostrophe despite the government's preoccupation 